\title{
Holocene Glacier Fluctuations
}

\section{by Gerald Osborn and P. Thompson Davis}

\begin{abstract}
Contemporary glaciers provide a record of relatively small-scale Holocene climatic fluctuations through modern and historical accounts of their advances, retreats, and surges. The stratigraphy, geomorphology and chronology of glacial and glacio-fluvial sediments can also reveal aspects of the climatic record in terms of glacial fluctuations. This article reviews some recent work on terminal and lateral moraines, sediments in lakes downstream from glaciers, and regional and global correlation of data on the past 8000 years or so. (Ed.)
\end{abstract}

\section{The Holocene Epoch}

The last great ice sheets to cover significant portions of North America and Eurasia retreated prior to 10,000 years ago. The ensuing interglacial interval probably has not differed much from previous interglacial intervals in terms of climate and natural environment, but because it is the most recent one, and the one we are still living in, it has been separated out from the rest of the Quaternary Period as the Holocene Epoch. Climate-driven environmental change, at a scale smaller than that of the Quaternary as a whole, has been characteristic of the Holocene, as manifested in several physical and biological systems, including glaciers.

Approximately one-third of the global glacier ice present during the last glaciation survived the post-glacial warming, and the remaining glaciers have continued to fluctuate. Presumably, climate fluctuations characteristic of the Holocene were operative as well during the Pleistocene, but are difficult to decipher because of overwhelming by the larger cycles that caused major glaciations. Hence study of Holocene glaciers is suitable for the analysis of relatively small-scale climatic variation. Furthermore, sediments containing evidence of Holocene environmental change, including glacier fluctuations, are at the top of the geological pile and thus relatively accessible and datable.

\section{Historical Records}

Historical data are available for reconstruction of recent glacier variations. In the European Alps, landscape artists and other careful observers produced seattered records of glacial extents over the past three centuries (e.g. Orombelli and Porter, 1982). In the New World the oldest records are typically on the order of $80-100$ years old. Government geological surveys in some countries systematized observations in the 20th century, and the advent of aerial photography allowed a wealth of detail to be collected. The International Association of Hydrological Sciences is sponsoring a World Glacier Inventory (IAHS, 1980) and has published volumes on fluctuations of selected glaciers throughout the world, beginning in 1959 (e.g. Müller, 1977).

\section{Moraines}

Data beyond the realm of historical records must be obtained from the sedimentary and/or geomorphological record. Most studies of alpine glacial history have concentrated on terminal moraines, which mark the limits of glacier advances. Dating these moraines provides a chronology of maximum extents but, of course, reveals nothing of the state of the glacier between advances. Moreover, a younger advance will tend to destroy evidence of any older, less-extensive ones. This is indeed the case in some regions where glacier growth in the past few centuries appears to have been the most extensive of the entire Holocene; earlier terminal moraine records are not preserved.

Dates of end moraines most commonly have been determined by radiocarbon dating of overlying organic matter, or using known ages of overlying tephra (Fig. 1, Davis and Osborn, in press), both techniques yielding minimum dates for the moraines. Where several Holocene-Late Pleistocene tephras are present they may serve to bracket moraine ages between known dates. In a few cases datable organic matter (charcoal or paleosols) has been found within the till of a moraine and may directly date the respective glacial advance. Moraines of the order of hundreds or even thousands of years old can be approximately dated using lichenometry or dendrochronology (Porter, 1981).

Even where end moraines are accurately datable, the resulting record is extremely discontinuous. Other techniques may provide information on intermediate extents of glaciers. One involves finding and dating overridden in situ tree stumps in contemporary glacier forefields, exposed by rapid retreat of glaciers over the past century (e.g. Ryder and Thomson, 1986).

Another extremely promising approach utilizes stratigraphic units in lateral moraines. While suceessive glacial advances in a valley will deposit terminal moraines in different places, these same advances may deposit and stack lateral tills in the same place each time (Osborn, 1986). Thus a

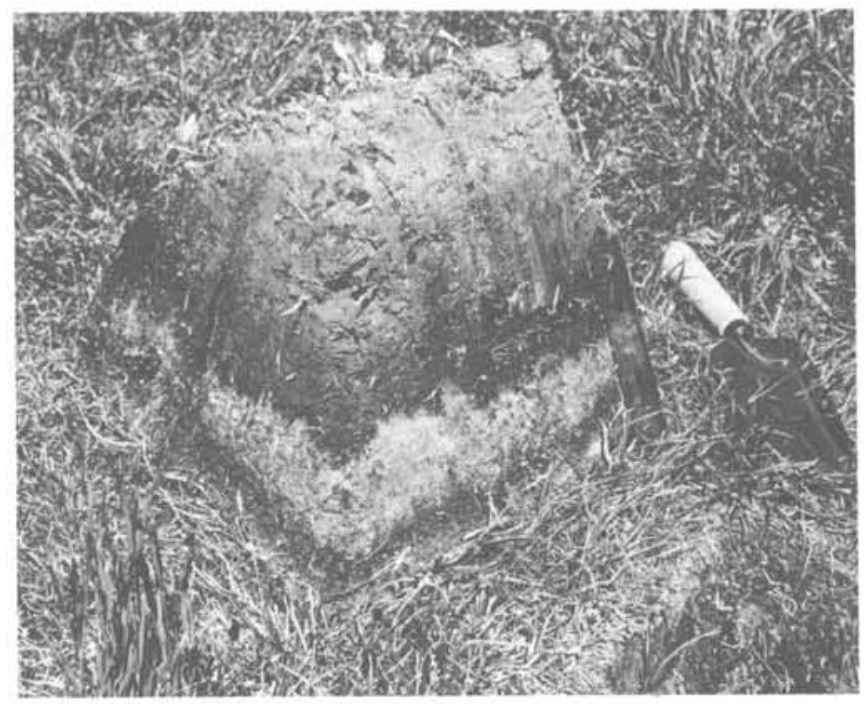

Figure 1: Inverted block of soil excavated from a cirque moraine in the Selkirk Mountains of British Columbia. The light-coloured material below the middle dark-coloured band is tephra from the Bridge River vent in SW British Columbia, and the mediumcoloured material above the dark band is tephra from southern oregon (Mazama). 
single lateral moraine may contain tills of several advances. In many cases the unconformities between these tills are very difficult to detect, but in other cases vegetation becomes established on a moraine during glacier recession. If the moraine is later buried by younger till during a re-advance, the vegetation (in the form of tree stumps, paleosols, etc.) may become exposed by erosion on the flank of the moraine. Radiocarbon dates on the organic matter indicate times of glacier recession and bracket times of glacial advance. Lateral moraine studies have been most comprehensive and successful in the European Alps; other work has been done in Scandinavia, the Himalayas, the Canadian Cordillera, and New Zealand (Griffey and Worsley, 1978; Röthlisberger et al., 1980; Gellatly et al., 1985; Kyder and Thomson, 1986).

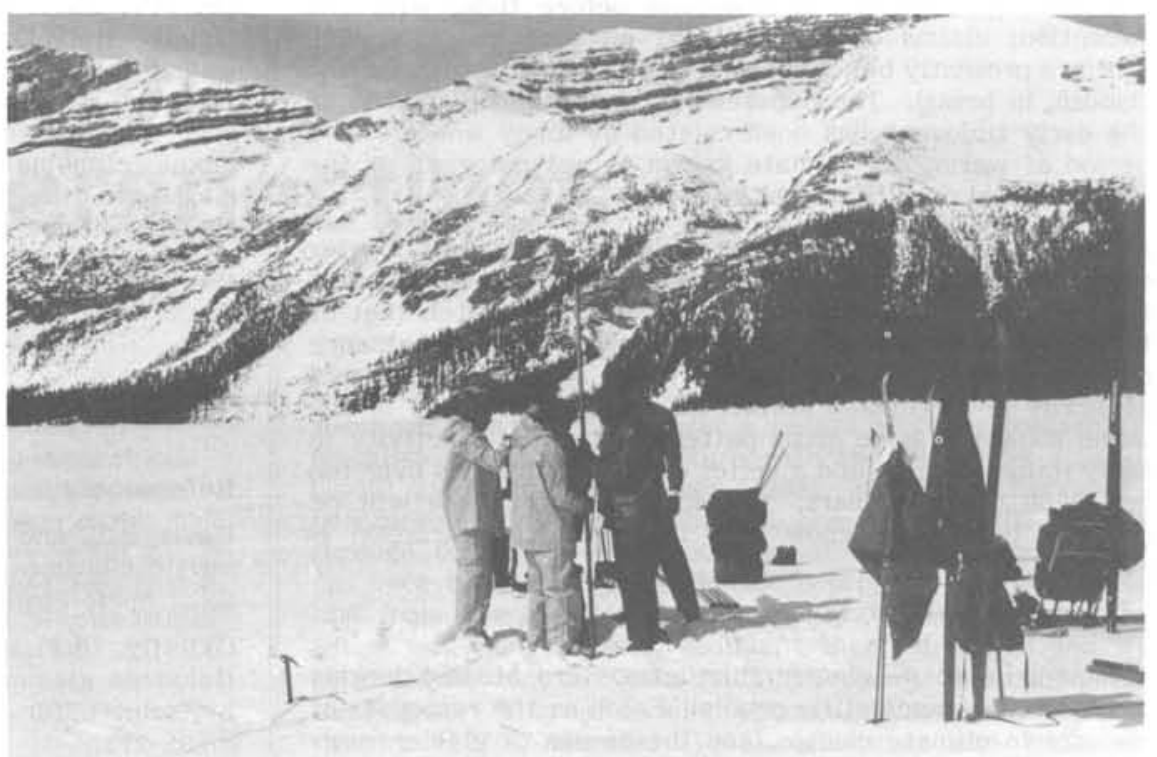

\section{Glacio-fluvial Sediments}

Radiocarbon dates are sometimes available from glaciofluvial sediments (e.g. outwash, ice-contact deposits) associated with glacial advances. However, it is very difficult to prove time-equivalence between a particular body of fluvial sediment and a specific end moraine or other evidence of ice extent.

In an attempt to obtain more continuous records than those produced by the above methods, some workers are analyzing lacustrine sediments in lakes downstream of glaciers (Fig. 2). The rationale is that silt production increases when glaciers are extensive (i.e., more of the drainage basin is glaciated), and vice versa. Silt content in a sediment core can be determined by mechanical analysis, with $\mathrm{x}$-ray techniques, or by inference from organic-matter content. Organic matter, tephra and/or varve counts can provide age control. Results from such studies have in many cases shown good agreement with those obtained from moraine investigations (e.g. Leonard, 1986).

\section{The Holocene Record}

Changes in most glaciers are driven by climate, although some experience periodic surges unrelated to climate, and tidewater glaciers are subject to fluctuations that are only partly related to climate. Glacier historians seek to understand whether climate patterns were generally synchronous in different regions. Results from around the world, obtained from the kinds of studies described above, are generally consistent for late Holocene time (Porter, 1981). In most glaciated areas there was a series of minor glacial advances in the last several centuries (Fig. 3), a period that is popularly known as the "Little Iee Age." This phase of expansion apparently began 400-800 years ago, depending on the area, and culminated between the 17th and 19 th centuries. In some areas glaciers reached their maximum Holocene extents at this time. General retreat of most glaciers, continuing to the present day, was in progress by the late 19 th century.

Except in a very general sense, no consistent global pattern has emerged for the Holocene prior to the Little Ice Age, though few data are yet available for most of the world and dating resolution is often poor. Some of the disagreement is, however, likely due to differences in climatic history.

In North America, glacial advances similar in magnitude to those during the subsequent Little Ice Age are known to have peaked between 3000 and $2000 \mathrm{yBP}$ and to a lesser degree around $1000 \mathrm{yBP}$, though some glaciers were also advaneing around $6000-5000 \mathrm{yBP}$. There is no evidence of
Figure 2: Coring lake sediments from the frozen surface of Bow Lake in the Canadian Rockies, in a search for evidence of fluctuations in nearby glaciers.

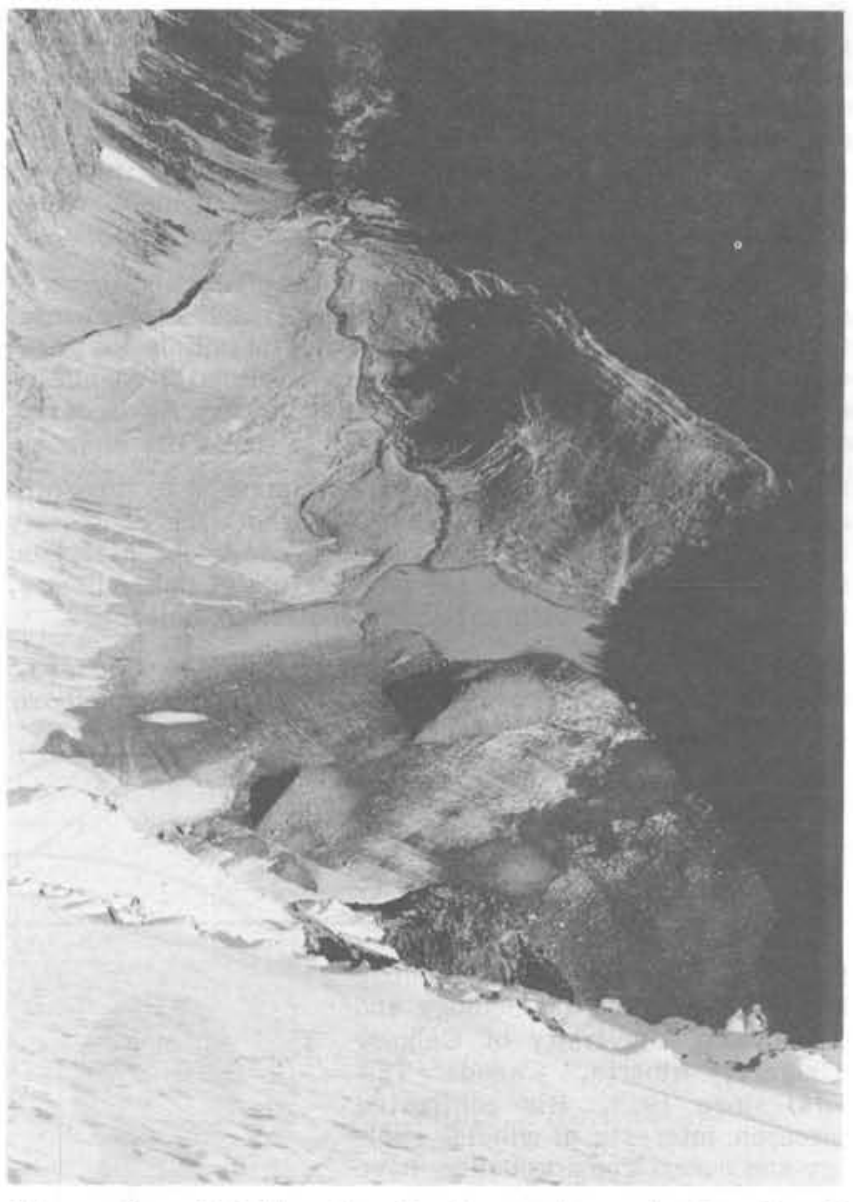

Figure 3: "Little Ice Age" moraine of the Cavell Glacier in Jasper National Park, Alberta. Tree-ring studies indicate the oldest part of the moraine was deposited at about 1700 A.D. The pond marks the present terminus of the glacier. 
extensive glaciers in the Holocene before then, with one exception; claims of a significant advance ca. 8500-8000 yBP are presently being debated in the literature (Davis and Osborn, in press). The apparent general lack of activity in the early Holocene has been related by many workers to a period of warm, dry climate known to palynologists as the Hypsithermal or Altithermal Interval.

In Europe and Asia there is evidence of several glacier advances of roughly Little Ice Age magnitude over the last 5000 years; their timing does not necessarily mateh that of the known North American advances. There is also evidence of an advance at ea. $7500 \mathrm{yBP}$, prior to which glaciers were generally in a recessed state. Data from elsewhere in the world show the same gross pattern of general inactivity in early Holocene time and a series of minor advances over the last 5000 to 7000 years. Considerably more data will be required before we know how much of this variation is genuine.

\section{Applications}

Although Holocene glacier fluctuations are studied largely to resolve basic scientific problems such as the responses of glaciers to climate change, and the causes of glacier surging, there are also consequences for water resources and for mining, engineering, and agricultural endeavors in high mountain regions (e.g. Meier and Roots, 1982; Post and Mayo, 1971). In areas where tidewater glaciers occur, such as southeast Alaska, glacier fluctuations affect tanker shipping and other coastal operations.

The broadest and most valuable application of these glacier studies stems from the fact that glacier fluctuations in most cases are proxy indicators of climate change, an understanding of which is of obvious value to society, with consequences for food and water supply, energy production, and sea level. Glaciers are rather sensitive to climate; they are also surprisingly widely distributed, from polar latitudes to the equator, and allow comparisons to be made between many different geographic settings.

Limitations to the use of glaciers in paleoclimate work include poor dating resolution, incompleteness of record, inability to distinguish between specific climatic parameters, and different response times to climatic change of different glaciers because of variations in size, debris cover, and other variables.

Obviously, the best approach to paleoclimate is to integrate data from many sources. Glacier historians are constantly trading information with palynologists, dendrochronologists, isotope geochemists, and other interpreters of paleoclimate, in the tradition of interdisciplinary Quaternary science.

INQUA '87. Special Session 19: Holocene Glaciers. Organizers: P.T. Davis (U.S.A.) and G. Osborn (Canada).

Dr. G. Osborn has taught geology in the Department of Geology and Geophysies, University of Calgary (Calgary, Alberta, Canada T2N 1N4) since 1972. His contrasted research interests of glacial geology and desert geomorphology have led him to such remote places as the Desert of Death in Afghanistan and the Nanda Devi Sanctuary in the Garhwal Himalaya.
Dr. P.T. Davis teaches geology at Mount Holyoke College (South Hadley, Massachusetts 01075 , U.S.A.). He combines Quaternary and glaciological studies with alpine climbing in the Nun Kun massif in the Himalayas, Baffin Island, Antaretica's Taylor Valley, and several American ranges.

\section{References}

Davis, P.T. and Osborn, G., In press. Age of pre-Neoglacial cirque moraines in the central North American Cordillera. Géographie Physique et Quaternaire.

Gellatly, A.F., Röthlisberger, F. and Geyh, M.A., 1985. Holocene glacier variations in New Zealand (South Island). Zeitschrift für Gletscherkunde und Glazialgeologie, v.21 p.265-273.

Griffey, N.J. and Worsley, P., 1978. The pattern of Neoglacial glacier variations in the Okstindan region of northern Norway during the last three millennia. Boreas, v.7, no.1, p.1-17.

International Association of Hydrological Sciences, 1980. World Glacier Inventory: Proceedings of the Workshop at Riederalp, Switzerland. IAHS Publication No. 126, $351 \mathrm{p}$.

Leonard, E.M, 1986. Varve studies at Hector Lake, Alberta, Canada, and the relationship between glacial activity and sedimentation. Quaternary Research, v. 25, no. 2, p. 199-214.

Meier, M.F. and Roots, E.F., 1982. Glaciers as a water resource. Nature and Resources, v.18, no. 3, p. 7-14.

Müller, F., 1977. Fluctuations of Glaciers 1970-1975, v. 3. International Association of Hydrological Sciences and Uneseo, Paris, 269p.

Orombelli, G. and Porter, S.C., 1982. Late Holocene fluctuations of Brenva Glacier. Geografia Fisica e Dinamica Quaternaria, v. 5, no. 1, p. 14-37.

Osborn, G., 1986. Lateral-moraine stratigraphy and Neoglacial history of Bugaboo Glacier, British Columbia. Quaternary Research v. 26, no. 2, p. 171-178.

Porter, S.C., 1981. Glaciological evidence of Holocene climate change. In: Wigley, T.M.L., Ingram, M.J. and Farmer, G., (eds.), Climate and History; Studies in past climates and their impact on man, Cambridge University Press, Cambridge, p. 82-110.

Post, A. and Mayo, L.R., 1971. Glacier dammed lakes and outburst floods in Alaska. U.S. Geological Survey Hydrologic Investigations Atlas AS-455, 10p.

Röthlisberger, F., Haas, P., Holzhauser, H., Keller, W., Bircher, W. and Renner, F., 1980. Holocene climatic fluctuations - Radiocarbon dating of fossil soils ( $\mathrm{fAh}$ ) and woods from moraines and glaciers in the Alps. Geographica Helvetica, v. 35 , no. 5 , p. 21-52.

Ryder, J.M. and Thomson, B., 1986. Neoglaciation in the southern Coast Mountains of British Columbia: Chronology prior to the late-Neoglacial maximum. Canadian Journal of Earth Sciences, v. 23, no. 3, p. 273-287. 